\title{
COVID-19: The need of an integrated and critical view $^{1}$
}

Charbel N. El-Hani ${ }^{1,2,3^{*}}$ and Virgílio Machado ${ }^{2,4}$

\section{ABSTRACT}

To understand and act upon a complex reality like COVID-19, we need to integrate knowledge from different academic sciences, in interdisciplinary efforts, and academic knowledge and other knowledge systems, in transdisciplinary processes. Without an integrated view leading to socially robust orientations, we are less likely to successfully navigate our challenging times. However, COVID-19 became a "wicked problem", in which there is broad disagreement on what the very 'problem' is, and instead of a "whole-of-government, whole-of-society approach", we find partial solutions that fall short of dealing with the complex dilemmas posed by the wicked problem. To build an integrated view, different scientists and social actors should engage in trust relationships and accept mutual epistemic dependencies, as requisites for a concerted way of understanding and acting on the problem. This is particularly hard, however, in a wicked problem. In building an integrated view on COVID-19, the role of academic sciences should be surely recognized, but we should avoid turning this recognition into an advocacy for scientism. It remains necessary to recognize and value the plurality of knowledge systems that span over human history, as well as their integration for mutual learning and concerted action. It is worth briefly examining, then, an integration initiative in COVID-19 treatment, namely between traditional Chinese and Western medicine. Finally, an integrated and critical view of COVID-19 demands that we cast aside the myth of value-free science, consider the relationships between values and scientific work, and conceive how knowledge can be objective without being neutral.

Keywords: COVID-19; Knowledge Integration; Wicked Problems.

1 Instituto de Biologia, Universidade Federal da Bahia, Rua Barão do Geremoabo, s/n, Campus de Ondina, Salvador, BA, 40170-290, Brazil.

2 Instituto Nacional de Ciência e Tecnologia em Estudos Interdisciplinares e Transdisciplinares em Ecologia e Evolução (INCT IN-TREE), Rua Barão do Geremoabo, s/n, Campus de Ondina, Salvador, BA, 40170-290, Brazil.

3 Centro de Estudos Sociais, Universidade de Coimbra, Praça Dom Dinis, 77, Coimbra, 3000-104, Portugal.

4 Instituto Mãos da Terra (IMATERRA), Via de Penetração II, 939, sl. 20, Cia Sul, Simões Filho, BA, 43700-000, Brazil.

* Corresponding author. $\ \mathrm{E}$-mail address: CN El-Hani (charbel.elhani@gmail.com), V. Machado

(virgilio@multilateral.com.br)

1 This article was developed from ideas initially published in the blog Darwinianas, associated with the National Institute of Science and Technology in Interdisciplinary and Transdisciplinary Studies in Ecology and Evolution (INCT IN-TREE), published in April 21 2020 (https://darwinianas.com/2020/04/21/covid-19-a-necessidade-de-um-olhar-transdisciplinar/). 


\section{SIGNIFICANCE STATEMENT}

An integrated view, both inter- and transdisciplinary, is needed to deal with COVID-19. The pandemic became, however, a "wicked problem", in which there is broad disagreement on what the very 'problem' is. We can see this, for instance, in the false dilemma between human and economic health posed by some political leaders, decision-makers, journalists, and members of the general public. To build an integrated view is difficult when dealing with "wicked problems", as different stakeholders tend to favor their preferred partial solutions. Moreover, there are epistemological challenges to build an integrated view, due to stakeholders' different perspectives, values, interests, and knowledge, which become even harder in a wicked problem. In building an integrated view, the role of the academic sciences should be recognized, but this recognition should not be conflated with scientism, and the relationships between values and scientific work should be critically appraised.

INTRODUCTION: for an integrated and critical view of the COVID-19 pandemic

When the first news about COVID-19 disembarked in Brazil, some experts calmed down their followers based on the fact that the available data by then indicated a case fatality rate (CFR) of $3 \%$, what was low compared to other coronavirus-caused diseases like SARS (CFR=9.6\%) and MERS $(\mathrm{CFR}=34.3 \%)^{2}$. Moreover, mostly elderly people with an already fragile health, particularly susceptible to infections and ensuing complications, would die. We could follow with our normal lives.

When these videos, texts and interviews became viral in the social media, it was already becoming clear that many people, even those with the best of intents, were seriously wrong in their understanding of the situation. The CFR for COVID-19 is higher than that observed for seasonal influenza (Wu and McGoogan 2020) and closer to that of SARS, and, above all, COVID-19 has already killed more people than SARS and MERS combined (Mahase 2020).
But there is no need to consider estimates of CFR to understand we are facing quite a serious disease. What is most important is a crucial difference between the viruses that cause SARS and COVID-19, despite the fact they show $79-82 \%$ sequence identity (Chan et al. 2020; Lu et al. 2020): the coronavirus SARS-CoV-2, which causes COVID-19, spreads more easily among people than the coronavirus SARS-CoV, which causes SARS (Liu, Y. et al. 2020). That is, COVID-19 is alarmingly contagious, leading to greater case numbers. This is the major reason for the gravity of the disease, as it poses an immense challenge even for the best prepared health systems, let alone to the precarious ones that prevail in countries around the world. As of May $13^{\text {th }}$ 2020, the World Health Organization (WHO) Situation Report 114 registered 4170424 confirmed cases and 287399 deaths from COVID-19 around the world ${ }^{3}$.

It is interesting to ask, then, why experts, even when they had good intentions, could be so wrong about the pandemic. We consider that a fundamental reason for this equivocation, as well as to many others we 
are witnessing along these strange times, lies in the absence of a proper view of the whole picture. What we intend to discuss here, then, is the need of an integrated view on complex realities, such as that of the COVID-19 pandemic. By an integrated view, we mean a view that goes beyond health sciences into the realm of other domains of academic sciences ${ }^{4}$, and, also, beyond academic sciences themselves, into the realm of other knowledge systems. In other words, we will be considering interdisciplinary and transdisciplinary approaches.

Inter- and transdisciplinarity in research and action on COVID-19 as a wicked problem

Transdisciplinarity, which aims at integrating the bodies of knowledge from academic sciences and from other social groups, is particularly important in a socioenvironmental problem with the nature and extent of COVID-19. Classical public health measures, including intensive contact tracing, quarantine, physical distancing ${ }^{5}$, and community transmission containment (Wilder-Smith and Freedman 2020), are needed to control the pandemic, especially in the absence of vaccines and approved prophylactic and therapeutic agents. The effective use of these public health measures demands that academic scientists, decision-makers, political leaders, public agencies, the media, business companies, organizations from the third sectors work together, and, also, that they integrate their understandings of the situation, built from the perspectives of their own bodies of knowledge.

Knowledge integration and, consequently, transdisciplinary practices are needed not only for democratic reasons, but also for the effectiveness of the measures themselves. Accordingly, academic scientists, who too often assume a hierarchical view on the knowledge of other social groups, should strive for assuming a more dialogical position, which lead to a horizontal (i.e., nonhierarchical) relationship. Provided they assume such a dialogical attitude, they would be quite helpful for scaffolding the search for a coherent framework that benefits from the best contributions from all the stakeholders, due to their ingrained ethos and mode of conducting efforts to comprehend the world (when well-educated for the practice of academic research, not only conceptually and methodologically, but also epistemologically and ethically). While it is correct that these contributions may be

\footnotetext{
4 Along this paper, we will systematically use the expression "academic science" to refer to scientific research as carried out in academic institutions such as scientific societies, museums, botanical and zoological gardens, universities, research centers, i.e., the organizational apparatus underlying the practice of Western, modern science. We avoid using simply the term "science" because we do not intend to take a position regarding the demarcation between Western, modern science and other knowledge systems, and, also, because we intend to leave it open the possibility that the latter can be also treated as "sciences" in their own right. In fact, the demarcation problem is currently of limited interest to us. We are much more interested in inquiring into the practices and heuristics that are shared or not by academic science and other knowledge systems (El-Hani, C. N., Poliseli, L. and Ludwig, D. 2020, Beyond the divide between traditional and academic knowledge: causal and mechanistic explanations in a Brazilian fishing community, under review in Studies in History and Philosophy of Biological and Biomedical Sciences), which can be explored by means of a methodology of partial overlaps (Ludwig and El-Hani 2020).
}

5 We do not use the expression "social distancing", often employed in the literature and media cover on COVID-19 (including the cited work), because we agree with the Mind the Gap campaign, from the international foundation Human Rights in Mental Health-FGIP, which considers this expression a damaging one, especially for those in more isolated positions in society: persons with psychosocial and physical disability, as well as elderly persons who reside in care homes (see https:/l www.covidandmentalhealth.eu/?fbclid=IwAR1_dpTaT6gtMUCxkr7yBw3NMEZHvDS6owlYMJRUGfoBXgPDuMNzzTsa7_U, Accessed May $11^{\text {th }}$ 2020). In the attempt to control the spread of COVID-19, we need physical distancing with social solidarity, not social distancing and social isolation. 
evidence, scientific (academic) theories and models, they may be also knowledge from other sources. Community leaders, for instance, will be in an irreplaceable position for understanding the social dynamics of the communities where the public health measures are to be applied. Healthcare workers will have inestimable knowledge on the dynamics of care for patients affected by COVID-19, in their diverse severity levels. Psychologists will be especially important for handling the mental distress that comes with physical distancing and isolation. We will need the best expertise from educators to learn how to engage our children with teaching and learning practices in the home school we were forced to put to work. Evidently, these examples can be extensively multiplied, but the former suffice to establish that, albeit we do need academic knowledge, we need more than academic knowledge to handle the pandemic, and, in fact, any other complex socioenvironmental problem in the real world.

It is no surprise, then, that the need for an interdisciplinary and transdisciplinary approach to COVID-19 has been unfolding itself, in a domino effect, with different knowledge fields and social actors engaging in contributing to our efforts to face the challenge. For instance, studies on public health and epidemiology showed that COVID-19 has an amazing capacity to spread through the populations (Liu, Y. et al. 2020). In Brazil, the Oswaldo Cruz Foundation pointed out in a press note ${ }^{6}$ that in the week between March $15^{\text {th }}$ and $21^{\text {st }}$ the number of hospitalizations for respiratory problems was ten times higher than the historical average. And the curve continues to grow exponentially, confirming that the Brazilian health system is at high risk of collapsing, as it already happened in states like Amazonas and Ceará. This was in fact highly predictable, given the experience of countries that have been affected earlier, such as Italy and Spain, and saw their health system be overwhelmed to the point of a public health tragedy.

The overwhelming reality posed by a disease with alarming rate of spread through the population transferred an important part of the crisis to different societal sectors, dealing with logistics, infrastructure, industrial capacity to produce medical equipment and hospital supplies, and international trade for obtaining those equipment and supplies that cannot be produced in a given country.

When public health measures like quarantine and physical distancing were announced as the best possible measures in the current circumstances to halt the pandemic, leading to the interruption of most economic activities, new social actors were brought to the scene. We increasingly saw the participation and actions of businessmen (and women) apprehensive about the economic losses for their enterprises, politicians worried about the repercussions for their governments and voting chances, and economists concerned with recession and other economic problems ensuing from those measures. A problematic dichotomy between economic health and pandemic control was posed by some, without realizing that this is a much more complex case, with important dilemmas, requiring a careful costbenefit analysis that have been showing, in the end, that the costs of the public health measures may be smaller than the

6 See, e.g., https://g1.globo.com/bemestar/coronavirus/noticia/2020/03/27/internacoes-por-problemas-respiratorios-estao-10vezes-maiores-que-a-media-no-brasil-aponta-fiocruz.ghtml, Accessed May 11 2020. 
consequences of not taking them at the appropriate time (Eichenbaum et al. 2020; Smith 2020). The death toll from failing to contain the virus will be more costly to society than the economic difficulties caused by the needed measures.

Contributions from the human sciences were fundamental when it was proposed the idea of "vertical isolation", i.e., limited to elderly people and groups at risk. Astonished by the naivety of the measure, experts from different human sciences had to remind decision-makers of the precarious housing conditions in countries like Brazil. In 2010, when the Brazilian economy was in much better health, 11.4 million Brazilians lived in what The Brazilian Institute of Geography and Statistics (IBGE) designates as "subnormal clusters" (in Portuguese, "aglomerados subnormais"), as analyzed by Pasternak and D'Ottaviano (2016) in a study on the conditions of living in these territories whose dwellers do not have access to a significant part of the essential public services. For instance, $12 \%$ of the residents in these communities do not have water supply, increasing to $40 \%$ in the North region. Whole families often live in such communities in households with a single room or in bigger houses, but occupied by large families including grandparents and grandchildren. It is simply impossible to do any sort of effective vertical isolation in such conditions that are widespread not only across Brazil, but also in many other countries around the world.

As physical distancing measures were established in many countries, psychologists engaged in investigating anxiety, distress and breakdowns in mental health among the persons kept in their homes or feeling threatened by the disease or the consequences of the public health measures themselves. WHO published, for instance, considerations on the mental health and psychosocial well-being of different groups affected by the pandemic ${ }^{7}$. Effects on children and their schooling also deserved the attention of psychologists, pediatricians, educational researchers, and educators (see, e.g., Orgilés et al. 2020; Viner et al. 2020; Wang et al. 2020). Social and behavioral sciences were also summoned to answer how human behavior could align to the recommendations of public health experts and epidemiologists, such that the large-scale behavioral changes required to face the pandemic could take place and the psychological burdens on the individuals could be properly handled (Van Bavel et al. 2020). Once again, we needed the help of social and political scientists to understand the reciprocal relationships between social networks and pandemic control measures: how does social cohesion affect pandemic control? Can pandemic control measures undermine social cohesion? (Dayrit and Mendoza 2020).

Experts in public health and social work contributed by discussing how to mitigate the stigmatization of persons affected by the disease (Logie and Turan 2020). Anthropologists and political scientists dedicated themselves to analyze several social and political aspects of the pandemic and its control (e.g., Leach 2020). Philosophers, social scientists and political scientists have been playing important roles in the debates about what does COVID-19 mean for our way of living and how the postpandemic world may look like depending on whether and how we decide to change our 
societies (see, e.g., Latour 2020; Santos 2020). Nonetheless, these debates have been also benefitting a lot from the contributions of community and Indigenous leaders, as well as other social actors (see, e.g., an interview with the Indigenous leader Ailton Krenak in the newspaper Estado de Minas $\left.^{8}\right)$.

To understand why we have been cornered by one emerging epidemic after the other in the last decades, we needed the contribution of ecologists and environmental scientists who can elucidate how the demise of native vegetation in different parts of the world due to conversion to other kinds of land use, such as agriculture, the acceleration of the loss of animal habitats due to global climate change, and our habits of consuming wild animals may expose us to pathogens that can cross the species barrier (Armostrong et al. 2020; Nabi et al. 2020)9 . Surely, this is knowledge that can also lead us to ponder on how to change our relationships with ecological systems and other living beings in order to decrease the likelihood of new pandemics in the future.

Being COVID-19 one among many zoonotic diseases, veterinary scientists also brought invaluable contributions to our understanding of the ecology of such emerging diseases (Bonilla-Aldana et al. 2020), while ecologists helped us model how the pandemic expands in space and time (Rangel et al. 2020). Moreover, Earth scientists, ecologists and environmental scientists brought about resources for the general population and decision-makers to monitor the progression of the pandemic ${ }^{10}$. We could multiply these examples, but the ones mentioned above are enough to deliver the message.

To take advantage of the contributions from diverse academic fields and social actors in order to build a transdisciplinary approach to the pandemic is crucially important. In the absence of a transdisciplinary process that can lead to socially robust orientations (Scholz and Steiner 2015) towards the control, prophylaxis, and therapeutic of COVID-19, and the mitigation of the side effects of the public health measures needed to contain it, it will be less likely that we successfully navigate the pandemic and post-pandemic times. In the countries overwhelmed by COVID-19, the pandemic became a "wicked problem", i.e., a problem in which there is broad disagreement on what the very 'problem' is (Rittel and Weber 1973; Roberts 2000). We can clearly see this when political leaders, decision-makers, the media, and the general public get stuck in the false dilemma between human and economic health. Worse still, when the problem is not consensually stated to a significant extent, the search for solutions becomes openended, with different stakeholders championing alternative solutions and competing with one another to frame 'the problem' in a way that directly connects their preferred solution and their preferred problem definition, and, besides, fulfills their own interests and pleases their own values.

We think the framing of COVID-19 as a

8 Symptomatically, the interview is entitled after the following statement by Krenak: "The mode of functioning of mankind has entered into a crisis" (free translation from the Portuguese by the authors). Available at: https://www.em.com.br/app/noticia/ pensar/2020/04/03/interna pensar,1135082/funcionamento-da-humanidade-entrou-em-crise-opina-ailton-krenak.shtml, Accessed May $10^{\text {th }} 2020$.

9 For a good media article on this issue, see https://www.theguardian.com/environment/2020/mar/18/tip-of-the-iceberg-is-ourdestruction-of-nature-responsible-for-covid-19-aoe, Accessed May $10^{\text {th }} 2020$.

10 See, e.g., the web portal Bahia COVID-19 (http://portalcovid19.uefs.br/, Accessed May 11th 2020). 
wicked problem provides a relevant interpretation of what has been going in many countries around the world when trying to face the pandemic, such as UK, Sweden, US, Brazil, and others. In this situation, the problem-solving process needed to control and eventually overcome the pandemic, and to rebuild the social and economic framework of a country and even of the world, which would be already quite complex and full of constraints, becomes even worse. After all, there is no integrated understanding of these very constraints, which keep changing in a complex way as the many stakeholders fail to communicate, to integrate their perspectives, to act in concert, making it less and less likely that we reach the "whole-of-government, whole-ofsociety approach" needed to deal successfully with pandemics like COVID-19 (Lau et al. 2020), as well as other similarly complex global problems. Instead of such an integrated approach, leading to socially robust orientations, what we will find is a series of partial solutions from different perspectives, held by different stakeholders, which will inevitably fall short of dealing with the complex dilemmas posed by the wicked problem.

Epistemologically, this has partly to do with the difficulties of building an integrated view. Surely, this is by no means a sufficient explanation of what we witness now in the way the affected countries have been dealing with COVID-19, as there are numerous political, social, economic, behavioral determinants to take into account.

But nonetheless to recognize the epistemological challenges at stake is also important. To build an interdisciplinary view, we need to deal with the fact that different academic fields formulate their research problems in different ways and do not share all their practices for building and validating knowledge, or all their values towards what constitutes knowledge and how to handle the relationships between knowledge production and use in society. If we turn now to transdisciplinary processes, they tend to be even more complicated, as we need to deal with the different perspectives, values, interests, and knowledge of heterogeneous stakeholders. To confront a complex problem like COVID-19, we need that different scientists and social actors build trust relationships and accept mutual epistemic dependencies (Andersen and Wagenknecht 2013) in order to build a concerted way of understanding and acting on the problem. This will be hard enough when they are all united towards a common goal. Imagine then how hard all this will become if they do not even share the ways they frame the problem, i.e., if the problem is not only complex, but also wicked. Then, we will witness stakeholders acting in an uncoordinated manner, sending different and conflicting messages to the public, working ones against the others in their search for partial solutions, and all this will conspire to bring about a public health disaster.

\section{Valuing both academic knowledge and the ecology of knowledges in pandemic times}

In a serious situation like the one we are living, it has been celebrated that, at least, scientific research came to be revalued by a good part of the population in countries like Brazil and the US (e.g., Leite 2020; USA Today Editorial Board 2020). This comes indeed as a welcome wave against the antiscientific attitude that has been prevailing in several societies around the world, putting us at risk of wasting a lot of knowledge and experience brought about by the academic sciences. In these circumstances the 
discomfort disclosed by Brazilian evangelical leaders who complained about what they see as a "deification of science" during the pandemic can be even seen as a good sign ${ }^{11}$. Indeed, given the widespread antiscience positions in countries like Brazil and the US, the fact that governments refractory to academic expertise, like the current US government, needs to endorse the role of academic science in facing urgent problems like the pandemic can be received as good news.

However, sometimes the celebration of science goes too far, as we see, for instance, in an opinion piece in the newspaper Público from Portugal, in which "progress" in history is basically reduced to the evolution of (modern) science and its technical applications (Assis 2020). Just to give an example, among several we could mention, from this perspective the development of agriculture in the Neolithic Revolution wouldn't say much about "progress" in human history, despite determining a major demographic shift for our species (Bocquet-Appel 2011). This exaggerated appreciation of academic science is clearly untenable. We need to be careful to avoid turning a recognition of the importance of academic sciences into a sheer advocacy for scientism, i.e., the idea that academic scientific knowledge is the only valid knowledge, or always the most valid knowledge in the history of mankind, or that this knowledge should fully dominate the arena of social decisions.

From a political point of view, this would mean to hit our already besieged contemporary democracies with the ghost of technocracy. From an epistemological perspective, it would entail a denial of the diversity of knowledge systems and epistemologies produced by mankind. Despite the welcome reappraisal of the role of the academic sciences that may emerge in post-pandemic times in social circumstances previously dominated by antiscientific attitudes, it remains equally necessary to recognize and value the plurality of knowledge systems that span over human history. We should also celebrate the ecology of knowledges that have survived modern times despite the epistemicide following European colonization, which wiped out from Earth many forms of knowledge and experience (Santos and Meneses 2010). In our efforts to deal with the global, pressing problems that challenge us, part of them also emerging from the technological interventions in nature that were made possible by the academic sciences, we need the contributions of many knowledge systems, dialoguing and even integrating with one another (Ludwig and ElHani 2020). Symptomatically, science-policy arenas such as the Intergovernmental Science-Policy Platform on Biodiversity and Ecosystem Services (IPBES) and the Convention on Biological Diversity (CBD) acknowledge the importance of Indigenous and local knowledge in conservation, supporting the diversity of knowledge systems (Díaz et al. 2015; Tengö et al. 2017).

We should not forget the past lessons of unrestrained scientism, such as, for instance, those provided by the replacement of the millennial irrigation systems from Bali's rice fields, managed through the mediation of Hindu-Buddhist water temples dedicated to the Goddess of the Lake (Dewi Danu), by technical-scientific irrigation 
systems associated with the Green Revolution (Lansing 2007). This was a scientistic decision of the Indonesian government, in the sense that it completely overlooked the role of the water temples because they were taken as mere superstition, nothing but remnants of the past. The new irrigation system had, however, disastrous consequences for rice cultivation in Bali, due to the uncontrolled proliferation of agricultural pests and water shortages. Rice harvesting in Bali decreased to less than half the production under the millennial irrigation systems. Thirty years later that scientistic decision, it was shown through computer simulation that the sequences of irrigation based on the water temples network reached optimal or nearoptimal scales of coordination in water management, and were in fact superior to the ones imposed by the technical-scientific system of irrigation introduced in the 1960s by Green Revolution agronomists (Lansing and Kremer 1993). Knowledge integration between the Green Revolution technicalscientific and the Balinese Hindu-Buddhist systems was also not successful, as shown by the continuous use of fertilizers introduced in the 1960s by the rice farmers, which has led to environmental problems, such as impacts on coral reefs in Bali's shore (Marion et al. 2005).

What about the use of traditional Chinese medicine (TCM) alongside with drugs arising from scientific (academic) knowledge in the treatment of COVID-19, which has taken place in China and are now part of ongoing clinical trials? Are they more likely to be similar to the troublesome juxtaposition of knowledge seen in the use of fertilizers by Balinese farmers? Or could they be closer to successful cases of knowledge integration, such as the bowhead whales (Balaena mysticetus) census carried out in Alaska incorporating both academic and traditional hunters' knowledge, which resulted in a more accurate estimate of the population than a census carried out using only scientific methods (Huntington 2000)? As knowledge integration can be made only partially (Ludwig and El-Hani 2020) and should be pursued without neglecting the very knowledge systems in their entirety, it is worth briefly examining the integration between traditional Chinese and Western medicine in COVID-19 treatment. As this is yet an ongoing investigation, we do not intend to present here any consolidated conclusion. This is reserved for the future. We will just make some brief remarks through exploring a report by Ren et al. (2020) on the use of TCM for treating COVID-19.

The use of TCM in epidemic diseases is not a novelty brought about by the current pandemic. During the SARS epidemic in 2003, TCM has already shown therapeutic effects. Back then, clinical trials have shown that a combination of traditional Chinese and Western medicine improved clinical symptoms of SARS patients, showing some positive effects (Jia and Gao 2003; Zhang et al. 2004). Application of TCM in the treatment of COVID-19 has been largely inspired by its previous use in SARS. More than 3100 medical staff specialized in TCM were dispatched to Hubei province, the original epicenter of the disease, specific TCM wards were set up, and a TCM scheme was included in the guideline for COVID-19 treatment (Ren et al. 2020). By the end of February, 60,107 COVID-19 patients had been treated by TCM. In 102 cases showing mild symptoms who received such treatment, clinical symptom disappearance time was shortened by 2 days, body temperature recovery time was shortened by 1.7 days, average length of hospitalization 
was shortened by 2.2 days, improvement rate of computed tomography (CT) image was increased by $22 \%$, clinical cure rate was increased by $33 \%$, and rate of progression to severe diseases was reduced in $27.4 \%$. In the treatment of severe patients, TCM was effective in shortening the average length of hospitalization and the time to virus-negative conversion by more than 2 days. Surely these outcomes should be taken cum grano salis as they are drawn from small samples in uncontrolled trials. As it is the case of most research on COVID-19 prophylaxis and treatment, it will be possible to reach more secure conclusions only after more studies are conducted, especially high-quality randomized control trials (RCTs) (Alexander et al. 2020). We do not intend, thus, to support the claim that the combination of TCM and Western medicine is effective in treating COVID-19. For that, we need to wait for more evidence (see more on the validation issue underlying these trials below). Perhaps they can be seen as promising results, but even this is not our major interest here. Rather, what mostly draws our attention in this report is how the authors intersperse arguments related to Western and Chinese medicine.

The TCM scheme included in COVID-19 treatment in China includes practices like acupuncture, but above all a number of decoctions using a diversity of herbal medicines (Ren et al. 2020). The qingfei paidu decoction (QPD), for example, consists of Ephedrae Herba, Glycyrrhizae Radix et Rhizoma Praeprata cum Melle, Armeniacae Semen Amarum, Gypsum Fibrosum, Cinnamomi Ramulus, Alismatis Rhizoma, Polyporus, Atractylodis Macrocephalae Rhizoma, Poria, Bupleuri Radix, Scutellariae Radix, Pinelliae Rhizoma Praepratum cum Zingibere et Alumine, Zingiberis Rhizoma Recens, Asteris Radix et
Rhizoma, Farfarae Flos, Belamcandae Rhizoma, Asari Radix et Rhizoma, Dioscoreae Rhizoma, Aurantii Fructus Immaturus, Citri Reticulatae Pericarpium, and Pogostemonis Herba. The very way Ren and colleagues argue in support of the successful use of QPD in COVID-19 treatment shows an integration with Western medicine. They discuss, for instance, how QPD may inhibit and alleviate the excessive immune and inflammatory response that is related to the more severe COVID-19 cases by regulating pathways related to immune response and cytokine action. They describe the case of a highly suspected COVID-19 case that was first treated using Western medicine, including the antiviral drugs oseltamivir and ganciclovir, and aerosol inhalation of recombinant human interferon a1b. The antiviral drugs were successful in promoting the virus-negative conversion of the patient, but the results from his chest CT showed that their lungs were still affected and worsening. QPD was then added to the treatment, and on the night of administration, his body temperature dropped to $36.2^{\circ} \mathrm{C}$, and subsequently tended to be normal. After 6 days, his chest CT showed lung improvement, with the inflammation being absorbed.

We can see how the analysis of the changes in the patient's condition is carried out by Ren et al. (2020) using a knowledge base from Western medicine. We can also witness how the treatment prescribed integrated TCM and Western medicine. But this does not mean that TCM decoctions are simply incorporated with no attention to the worldview in which they are embedded, as it often happens, for instance, with the introduction of acupuncture into Western medicine (Cant 2020). Ren and colleagues (2020) keep their allegiance to what they call the "holistic concept" of TCM, based on the 
balance of Yin and Yang, syndrome differentiation and treatment, and strengthening the body resistance to eliminate pathogenic factors. They call attention to the fact that TCM has thousands of years of experience in the practice of regulating the body and enhancing resistance to epidemic diseases. Notice, then, that the investigation on the efficacy and safety of combining TCM with Western medicine cannot be seen as playing the role of validating TCM itself, as many may think. As a knowledge system, TCM has been already validated throughout the history of its millennial use, and according to their own validity criteria. Empirical tests need to be carried out only for validating the integration between TCM and Western medicine to be used in hospitals for treating COVID-19. It is crucially important to differentiate between validating TCM as a knowledge system per se, as it is nothing but a neo-colonial perspective to require its validation from a Western scientific perspective, and validating its combination with Western medicine, which is a new development taking place in the contact zone between Chinese and Western knowledge systems.

It would be, no doubt, a tremendous waste of knowledge and experience to simply neglect putative contributions of TCM to our current health challenges (see Santos and Meneses 2010). Rather than placing one knowledge system against the other, it seems fair to say that the Chinese approach to COVID-19 treatment has at least searched for integration between them. It is not a minor thing, thus, that Ren et al. (2020) stress that (academic) scientific research should be carried out on the therapeutic role of TCM in COVID-19, as well as on its action mechanism. It will be interesting to see the outcomes of the ongoing clinical trials that include TCM, especially the RCTs, provided we understand, as discussed above, that we are not validating TCM in itself. What will happen, then, is that we will be in a better position to understand how successful integrating TCM and Western medicine can be.

Surely, there is much more to inquire into this case of medical knowledge integration that has been taking place in China since the SARS epidemic. For now, the brief comments above suffice to stress the takehome lesson that, despite the welcome recognition of the importance of the academic sciences for handling COVID-19, there is no reason to convert it into a scientistic defense, as if academic scientific knowledge would be an all-purpose remedy for each and every problem we need to face. Surely, a criticism of the hegemony of academic scientific knowledge in modern times should not convert itself, either, into an acceptance of a waste of the knowledge and experiences that modern scientific research has offered us in the last five centuries. In an ecology of knowledges capable of recognizing and valuing the epistemological diversity of our attempts to render the world and ourselves intelligible, we should not commit epistemicides like the ones perpetrated through the European colonization (Santos and Meneses 2010). In these times of the COVID-19 pandemic, we should not neglect the capacities shown by the academic sciences in advancing towards the prophylaxis and treatment of this challenging disease. But we should not either neglect the need of putting these sciences under a critical lens, especially in relation to the values and interests involved in their practice. 


\section{Recognizing social values and choosing sides in COVID-19 research}

It is widely accepted that science is not a value-free enterprise. For reasons of space, we will not expound here the arguments that support this claim, but just refer the reader to relevant literature (e.g., Douglas 2009; Kincaid et al. 2007; Kitcher 2001; Lacey 1999). We will rather depart from Lacey's argument that scientific knowledge and value judgments dialectically interpenetrate one another, and, accordingly, values may legitimately affect the methodological decisions shaping scientific research. Values particularly affect scientific inquiry in terms of what questions receive priority, among the multifarious ones we may ask about the world around us and within us (Barker and Kitcher 2013). After all, scientific research does not intend to establish which claims are true, since a myriad of true claims are simply irrelevant. It is surely irrelevant to establish what is the truth of the number of ants now inhabiting my house, just to give a trivial example. Scientists seek, rather, to establish meaningful, relevant truths, but this should immediately lead us to question to whom are the truths at stake relevant, to whom are they meaningful. We might answer that the relevant truths are the ones "we" want to know. But who are "we"? Mankind is obviously subdivided in groups, and groups, just as persons, have different interests and different goals to which academic research might contribute. That is, what is a relevant question to ask will vary alongside with the interests and goals of different human groups. And, moreover, these different interests and goals often conflict with one another. This entails that different conflicting interests and goals may eventually receive more attention than others, as funding and human labor for scientific research are evidently limited. Values play an especially important role, then, when priorities for research are established by governments, funding agencies, corporate leaders, scientific communities, labs, and research teams. It is not by chance, then, that biomedical research has systematically given priority, both in funding and effort, to cardiovascular diseases, cancers, mental diseases, which often affect the more wealthy social groups and, also, more capable of paying for the treatments, than tropical diseases or nutritional problems, which mostly affect the less favored social groups and countries (see, e.g., Barrenho et al. 2019; Fitzpatrick et al. 2017; Saviano et al. 2019). Or in agronomic research studies benefitting agrobusiness have received much more funding and effort than those focused on family farming or agroecology (see, e.g., Lacey 2015; Vogeler [1981]2019). When we consider the prioritizing of research goals, the relationships among academic sciences, politics and social values become all too clear, showing how untenable is the myth of a neutral science (which does not mean that we cannot have objective knowledge, since objectivity is not the same as neutrality, as we will see below).

As Lacey (2014) argues, there has been a widespread tendency for many decades now (we may even say, for most of the history of academic sciences) to prioritize research that may lead to technoscientific innovations contributing to economic growth and competitiveness. In his words, priority has been all too often given to research that promotes values of technological progress and of capital and the market. A particular set of research strategies have been favored in academic sciences due to their capacity to fulfill those values, which Lacey $(1999,2014)$ calls "decontextualizing strategies". These 
are strategies that represent phenomena in terms of their being generable from underlying order, namely, underlying structures, processes, and interactions of their components at different levels of organization, and invariant relationships that govern them, in short, as products of mechanisms. This gives rise to an important way of explaining phenomena, namely, mechanistic explanation (see, e.g., Bechtel and Richardson 2010), which underlies many if not most cases in which decontextualizing strategies have been remarkably fruitful and versatile. There is, however, a flip side of the power of such strategies: representing phenomena as they do decontextualizes them, i.e., they are dissociated from any relations they may have with social arrangements and human lives, human agency, value and sensory qualities. Whatever possibilities they may gain in virtue of their places in particular social, human and ecological contexts are lost from sight. And this brings about the limits of decontextualizing strategies.

Academic research is not monolithic, however, and we should never lose from sight the internal plurality of science (Santos 2010). This plurality is such that one of the most influential ideas about scientific work in the last three decades is the so-called "thesis of the disunity of science" (e.g., Dupré 1995; Galison and Stump 1996). When we think of the role of social values in science, we should be attentive, thus, to the fact that not all academic scientists and, even, not all scientific communities make the same choices. An all-encompassing discourse about (academic) science tends to be too simplistic, once we accept the perspective of the disunity of science.

We should recognize, then, that there are scientific studies that may be following other values than those of technological progress and of capital and the market. Lacey (2014) considers, for instance, studies that embed values that contest those dominating values in scientific work, such as agroecological research, which holds the values incorporated into the Precautionary Principle: social justice, respect for the full range of human rights, environmental sustainability, equity within and between generations, participatory democracy (UNESCO-COMEST 2005). These studies should deal with phenomena inherently linked with the social, human and ecological contexts in which they take place, and thus cannot be adequately pursued through decontextualizing strategies (or, at least, only through them). Rather, they demand what Lacey (2014) calls "context-sensitive strategies".

While it is true that those phenomena and strategies have been accorded low priority throughout most of the history of scientific research, they have been receiving increasing attention in the last decades, as complex and often wicked problems have been faced in a series of crisis impinging upon mankind, such as the socioenvironmental crisis generated by the forcing of planetary boundaries by our societies (Steffen et al. 2015), the global health crisis arising from emerging diseases, which are also related to socioenvironmental issues such as global warming, deforestation and so forth (e.g., El-Sayed and Kamel 2020; French and Holmes 2020; Nava et al. 2017), among many other such issues. We can say that these recent trends have increased the internal plurality of science, but this surely does not mean that the values of technological progress and of capital and the market have receded. On the contrary, they kept growing their magnitude and range of influence, and it is not necessary to expand the considerations on how the 
mismatch between these values and the global problems we face has a lot to do with the risks confronting our species in contemporary times.

But what all this may have to do with COVID-19 research? Once we assume a more critical perspective than the one often embedded in academic, especially natural scientists' training, and recognize that scientific work is inextricably linked to values and interests, we will unsurprisingly tend to leave aside the myth of value-free, neutral science. Then, we need to think about sides. Which sides do different research communities tend to choose? Which sides are we ourselves choosing? For instance, now that there are several vaccines for COVID-19 under development, will these vaccines be for selling or saving? Or, if both (as it seems likely), which inequalities will interfere with the access to vaccination around the world? Will access be really universal? Will it be fair? All these are welcome, even if yet unanswered questions, for anyone who recognizes the dialectical relationship between academic sciences and social values. In fact, for those who recognize, now in more general terms, the relationship between any knowledge systems and social values, as we just picked up academic sciences as a case in point because we were confronting the myth of value-free science.

Surely, we can at the same time defend a recognition of the epistemological diversity of human ways of making sense of the world and ourselves, and recognize and value modern, Western, academic sciences. Our position, however, is to advocate for academic sciences when they prioritize the values of social justice, respect for the full range of human rights, environmental sustainability, equity within and between generations, participatory democracy (Lacey 2014). It is clear that, to the extent that this is a normative position, others may take different ones. In particular, we think academic sciences should give support to the struggle for survival and life quality of many human communities who are victims of socioenvironmental injustices, for instance, in the distribution of COVID-19 cases and deaths. For instance, Brazilian Indigenous populations are at risk of being decimated by the pandemic ${ }^{12}$, and in the US African-American communities have been facing a disproportionate COVID-19 death toll ${ }^{13}$. We think modern sciences should take this role because they have been, after all, involved with the European colonization process, and are involved in hegemonic globalization processes that have much to do with the current pandemic crisis. This entails that one cannot avoid making value judgments on the roles academic sciences come to play in the approach to COVID-19, and, as value judgments are to be made, one cannot avoid taking sides. That's why we did not shy away from making our own position explicit above.

There are important judgments to be made concerning the intentions, values, interests, and political dimensions of scientific efforts towards the control, treatment and prophylaxis of COVID-19. It is worth asking, then, if the academic efforts in progress seek to reduce the social and environmental injustices that accompany the pandemic or can further aggravate them. To be sure, this should be answered on a case-

12 https://www.publico.pt/2020/04/11/mundo/noticia/indios-brasileiros-destruicao-trazida-covid19-tragedia-conhecida-1911930, Accessed May $11^{\text {th }} 2020$

13 https://www.nationalgeographic.com/history/2020/04/coronavirus-disproportionately-impacts-african-americans/, Accessed May $11^{\text {th }} 2020$. 
by-case basis. There are certainly those who advocate for a "whole-of-society" approach and are concerned about the most vulnerable communities (e.g., Lau et al. 2020). But there are also those who still think in colonial terms and easily talk about carrying out experimental testing of vaccines in populations that have been subjected to a plethora of injustices and discrimination during and after colonization, and up to the current world order. A case in point are the French physicians Jean-Paul Mira and Camille Locht, who proposed the experimental vaccination of African populations ${ }^{14}$. It is the very face of Injustice that African and other world populations have been often in the past denied access to treatments experimentally tested in those very populations, but then unequally distributed, according to the wealth of countries and social groups (Shah 2006).

Despite arguments for the relationships between social values and scientific work, many scholars will stick to the idea of valuefree science and appeal to objectivity as if it was the same as neutrality, even though it is widely recognized that there is nothing like neutrality, and, indeed, there is nothing less neutral than pretending to be neutral as a way of hiding the side one has chosen (see, e.g., Levins and Lewontin 1985). Scientific objectivity is not the same as neutrality, but rather demands that the different scientists' biases are recognized and exposed in the academic community, in order to be subjected to mutual criticism. That is, to be objective, it is vital that knowledge production (either academic or any other) be recognized as non-neutral. Not only objectivity is not the same as neutrality, but the misplaced assumption of neutrality undermines the very possibility of objective knowledge! We cannot elaborate on this issue here, but would like to highlight that these remarks are based on Longino's (1990) notion of interactive objectivity, which can be briefly explained as follows.

Longino stresses that scientific knowledge is fundamentally a social product and, as such, scientific objectivity should be conceived in terms that relate it directly to the social processes that generate such knowledge. In this sense, we can appeal to the Wittgensteinian insight that objectivity is tied to the practices of people, as well as to propositions (Shrader-Frechette and McCoy 1993). Objectivity can be seen, then, not as a property of knowledge claims that can be attributed to these claims in isolation. Rather, claims can only be said to be objective when conceived in terms of the practices employed by knowledge-producing communities. In a value-laden context, the best guarantee of objectivity is repeated criticism by these communities, unceasing investigation of a range of different value judgments, alternative evidence, and a variety of background hypotheses (ShraderFrechette and McCoy 1993). Objectivity cannot be defined, then, based on some fidelity of theories to facts, but based on the community practices of mutual criticism, which play, then, a key role in assuring the epistemic success of scientific work. It is evident that interactive objectivity, if born precisely from social criticism, cannot be linked to ethical or political neutrality. Objectivity is qualitatively distinct from neutrality.

On these grounds, Longino develops an epistemological theory she calls "contextual empiricism", in which a method of inquiry is 
regarded as "objective to the degree that it permits transformative criticism" (Longino 1990 , p. 76). For an epistemic community to be capable of transformative criticism, there must be open avenues for criticism, i.e., criticism should be an essential part of knowledge production by the community; shared standards, i.e., the community should share a set of cognitive values used to assess claims about the world; uptake of criticism, i.e., criticism should be able to transform cognitive and epistemic practices in the long run; and equality of intellectual authority among qualified practitioners (Longino 1990, Reiss and Sprenger 2017).

We can, therefore, both appeal to objectivity (in the sense of interactive objectivity, not neutrality, or naïve commitments to mirror relationships between knowledge and world), and at the same time acknowledge the dialectical relationships between social values and scientific work. More than that, from the standpoint of interactive objectivity, the latter acknowledgment is a precondition for reaching objective claims. Once we assume this perspective, we can see how crucial it is, for instance, the fact that WHO DirectorGeneral Tedros Adhanom Ghebreyesus has come out to publicly condemn the racist proposal of the two French doctors ${ }^{15}$.

\section{CONCLUDING REMARKS}

We defended the need of an integrated and critical view of the COVID-19 pandemic, interpreting it as a wicked problem that may benefit from inter- and transdisciplinary research and action, provided that the challenges for building such initiatives be successfully met. Inter- and transdisciplinarity may also favor mutual learning by heterogeneous stakeholders involved in handling the pandemic, who may then assume more conscious attitudes based on the whole picture of this pressing problem. Perhaps inter- and transdisciplinarity can be even thought of as social technologies to vaccinate societies that become dependent on "myths", by prompting the individuals to see in each one of them and in their collective, integrated action a response to our current scientific, social, environmental, health, and spiritual dilemmas.

\section{ACKNOWLEDGEMENTS}

CNEH is thankful to Boaventura de Sousa Santos for indicating the importance of discussing how the recognition of a role for academic sciences in the current pandemic shouldn't mean a neglect of the importance of equally recognizing the diversity of knowledge systems and epistemologies, and their contributions to navigate pandemic and postpandemic times. $\mathrm{CNEH}$ thanks $\mathrm{CNPq}$ (grant number 465767/2014-1) and CAPES (grant number 23038.000776/2017-54) for their support of INCT IN-TREE, CNPq for support in the form of productivity in research grant (grant number 303011/20173 ), and CAPES and UFBA for Senior Visiting Researcher Grant included in the CAPESPRINT Program, which funds his stay in the Centre for Social Studies, University of Coimbra, Portugal (grant number 88887.465540/2019-00).

\section{CONFLICTS OF INTEREST}

The authors have no conflicts of interest to declare. 


\section{CONTRIBUTION STATEMENT}

Conceived the presented idea: $\mathrm{CNEH}$, VM.

Wrote the first draft of the manuscript: CNEH, VM.

Reviewed and did the final writing of the manuscript: CNEH, VM.

Supervision: $\mathrm{CNEH}$.

\section{REFERENCES}

Alexander PE, Debono VB, Mammen MJ, lorio A, Aryal K, Deng D, Brocard E, Alhazzani W (2020) COVID-19 research has overall low methodological quality thus far: case in point for chloroquine/hydroxychloroquine. Journal of Clinical Epidemiology, in press, doi: 10.1016/ j.jclinepi.2020.04.016 Accessed 28 April 282020

Andersen H, Wagenknecht S (2013) Epistemic dependence in interdisciplinary groups. Synthese 190:1881-1898

Armstrong F, Capon A, McFarlane R (2020) Coronavirus is a wake-up call: our war with the environment is leading to pandemics. The Conversation. [https://theconversation.com/ coronavirus-is-a-wake-up-call-our-war-with-theenvironment-is-leading-to-pandemics-135023] Accessed 10 May 2020

Assis $F$ (2020) O vírus e a importância da ciência. Público, 21 March 2020. [https:// www.publico.pt/2020/03/21/opiniao/opiniao/virusimportancia-ciencia-1908801] Accessed 10 May 2020

Barker G, Kitcher P (2013) Philosophy of Science: A New Introduction. Oxford University Press, Oxford, UK

Barrenho E, Miraldo M, Smith PC (2019) Does global drug innovation correspond to burden of disease? The neglected diseases in developed and developing countries. Health Economics 28(1):123-143

Bechtel W, Richardson RC (2010) Discovering Complexity: Decomposition and Localization as Strategies in Scientific Research. MIT Press, Cambridge, MA, USA

Bocquet-Appel JP (2011) When the world's population took off: the springboard of the Neolithic demographic transition. Science 333:560-561
Bonilla-Aldana DK, Dhama K, Rodriguez-Morales AJ (2020) Revisiting the One Health Approach in the context of COVID-19: a look into the ecology of this emerging disease. Advances in Animal and Veterinary Sciences 8(3):234-237

Cant S (2020) Medical pluralism, mainstream marginality or subaltern therapeutics? Globalization and the integration of 'Asian' medicines and biomedicine in the UK. Society and Culture in South Asia 6(1):31-51

Chan JFW, Kok KH, Zhu Z, Chu H, To KKW, Yuan S, Yuen KY (2020) Genomic characterization of the 2019 novel humanpathogenic coronavirus isolated from a patient with atypical pneumonia after visiting Wuhan. Emerging Microbes \& Infections 9(1): 221-236

Chan-Yeung M, Xu RH (2003) SARS: epidemiology. Respirology 8:S9-S14

Dayrit MM, Mendoza RU (2020) Social cohesion vs COVID-19, preprint, [https:// papers.ssrn.com/sol3/papers.cfm? abstract_id=3555152] Accessed 10 May 2020

de Wit E, van Doremalen N, Falzarano D, Munster VJ (2016) SARS and MERS: recent insights into emerging coronaviruses. Nature Reviews Microbiology 14:523-534

Díaz S, Demissew S, Carabias J, Joly C, Lonsdale M, Ash N, Larigauderie A, Adhikari JR, Arico S, Báldi A et al. (2015) The IPBES Conceptual Framework-connecting nature and people. Current Opinion in Environmental Sustainability 14:1-16

Douglas HE (2009) Science, Policy, and the Value-Free Ideal. University of Pittsburgh Press, Pittsburgh, PA, USA

Dupré J (1995) The Disorder of Things: Metaphysical Foundations of the Disunity of Science. Harvard University Press, Cambridge, MA, USA

Eichenbaum MS, Rebelo S, Trabandt M (2020) The macroeconomics of epidemics. National Bureau of Economic Research (NBER) Paper Series, Working Paper 26882 [https:// www.nber.org/papers/w26882.pdf] Accessed 10 May 2020

El-Sayed A, Kamel M (2020) Climatic changes and their role in emergence and reemergence of diseases. Environmental Science and Pollution Research, in press, doi: 10.1007/ s11356-020-08896-w Accessed 11 May 2020 
Fitzpatrick C, Nwankwo U, Lenk E, de Vlas SJ, Bundy DAP (2017) An investment case for ending neglected tropical diseases. In: Holmes KK, Bertozzi S, Bloom BR, Jha P (eds) Major Infectious Diseases. International Bank for Reconstruction and Development/The World Bank, Washington, DC, USA, pp. 411-431

French RK, Holmes EC (2020) An ecosystems perspective on virus evolution and emergence. Trends in Microbiology 28(3):165175

Galison P, Stump D (1996) The Disunity of Science: Boundaries, Contexts, and Power. Stanford University Press, Stanford, CA, USA

Huntington HP (2000) Using traditional ecological knowledge in science: methods and applications. Ecological Applications 10(5): 1270-1274

Jia W, Gao W (2003) Is traditional Chinese medicine useful in the treatment of SARS? Phytotherapy Research 17:840-841

Kincaid H, Dupré J, Wylie A (2007) Value-Free Science? Ideals and Illusions. Oxford University Press, Oxford, UK

Kitcher P (2003) Science, Truth, and Democracy. revised ed. Oxford University Press, Oxford, UK

Lacey H (1999) Is Science Value Free? Values and Scientific Understanding. Routledge, New York, NY, USA

Lacey $H$ (2014) On the co-unfolding of scientific knowledge and viable values. In: Schroeder-Heister P, Heinzmann G, Hodges W, Bour PE (eds) Logic, Methodology and Philosophy of Science. Proceedings of the Fourteenth International Congress (Nancy). College Publ., Milton Keynes, UK, pp. 269-284

Lacey $H$ (2015) Food and agricultural systems for the future: science, emancipation and human flourishing. Journal of Critical Realism 14(3):272-286

Lansing JS (2007) Priests and Programmers: Technologies of Power in the Engineered Landscape of Bali. Princeton University Press, Princeton, NJ, USA

Lansing JS, Kremer JN (1993) Emergent properties of Balinese Water Temple networks: coadaptation on a rugged fitness landscape. American Anthropologist 95(1):97114
Latour B (2020) Imaginer les gestes-barrières contre le retour à la production d'avant-crise. AOC-Media [https://aoc.media/opinion/ 2020/03/29/imaginer-les-gestes-barrieres-contrele-retour-a-la-production-davant-crise/] Accessed 10 May 2020

Lau LS, Samari G, Moresky RT, Casey SE, Kachur SP, Roberts LF, Zard M (2020) COVID-19 in humanitarian settings and lessons learned from past epidemics. Nature Medicine 26:640648

Leach M (2020) Echoes of Ebola: social and political warnings for the COVID-19 response in African settings. Somatosphere: Science, Medicine, and Anthropology [http:// somatosphere.net/forumpost/echoes-of-ebola/] Accessed 10 May 2020

Leite C (2020) Valorização da ciência brasileira será legado pós-pandemia. OPovo, 5 April 2020 [https://mais.opovo.com.br/jornal/ reportagem/2020/04/05/valorizacao-da-cienciabrasileira-sera-legado-pos-pandemia.html/ Accessed 10 May 2020

Levins R, Lewontin R (1985) The Dialectical Biologist. Harvard University Press, Cambridge, MA, USA

Liu Y, Gayle AA, Wilder-Smith A, Rocklöv J (2020) The reproductive number of COVID-19 is higher compared to SARS coronavirus. Journal of Travel Medicine 27(2):taaa021

Logie CH, Turan JM (2020) How do we balance tensions between COVID-19 public health responses and stigma mitigation? Learning from HIV research. AIDS and Behavior, in press, doi: 10.1007/s10461-020-02856-8 Accessed 10 May 2020

Longino $\mathrm{H}$ (1990) Science as Social Knowledge: Values and Objectivity in Scientific Inquiry. Princeton University Press, Princeton, NJ, USA

Lu R, Zhao X, Li J, Nju P, Yang B, Wu H, Wang W, Song $H$, Huang B, Zhu N, Bi Y, Ma X, Zhan F, Wang L, Hu T, Zhou H, Hu Z, Zhou W, Zhao L, Chen J, Meng Y, Wang J, Lin Y, Yuan J, Xie Z, Ma J, Liu WJ, Wang D, Xu W, Holmes EC, Gao GF, Wu G, Chen W, Shi W \& Tan W (2020) Genomic characterisation and epidemiology of 2019 novel coronavirus: implications for virus origins and receptor binding. Lancet 395:565-574 
Ludwig D, El-Hani CN (2020) Philosophy of ethnobiology: understanding knowledge integration and its limitations. Journal of Ethnobiology 40(1):3-20

Mahase E (2020) Coronavirus: covid-19 has killed more people than SARS and MERS combined, despite lower case fatality rate. BMJ 368:m641

Marion GS, Dunbar RB, Mucciarone DA, Kremer JN, Lansing JS, Arthawiguna A (2005) Coral skeletal $15 \mathrm{~N}$ reveals isotopic traces of an agricultural revolution. Marine Pollution Bulletin 50(9):931-944

Nabi G, Siddique R, Ali A, Khan S (2020) Preventing bat-born viral outbreaks in future using ecological interventions. Environmental Research 185:109460

Nava A, Shimabukuro JS, Chmura AA, Luz SLB (2017) The impact of global environmental changes on infectious disease emergence with a focus on risks for Brazil. ILAR Journal 58(3):393-400

Orgilés M, Morales A, Delvecio E, Mazzeschi C, Espada JP (2020) Immediate psychological effects of the COVID-19 quarantine in youth from Italy and Spain. PsyArXiv preprints [https:// psyarxiv.com/5bpfz/] Accessed 10 May 2020

Pasternak S, D'Ottaviano C (2016) Favelas no Brasil e em São Paulo: avanços nas análises a partir da Leitura Territorial do Censo de 2010. Cadernos Metrópole 18:75-99

Rangel TF, Diniz-Filho JAF, Toscano CM (2020) Modelagem da expansão espaçotemporal da COVID-19 em Goiás. Nota Técnica 01 - Grupo de Trabalho em Modelagem da Expansão Espaço-Temporal da COVID-19 em Goiás [http:// estat.bio.br/covid/CovidGONT01.pdf] Accessed 10 May 2020

Reiss J, Sprenger J (2017) Scientific objectivity. In: Zalta EN (ed) The Stanford Encyclopedia of Philosophy (Winter 2017 Edition) [https://plato.stanford.edu/archives/ win2017/entries/scientific-objectivity/] Accessed 11 May 2020

Ren JL, Zhang AH, Wang XJ (2020) Traditional Chinese medicine for COVID-19 treatment. Pharmacological Research 155:104743

Rittel HWJ, Webber MM (1973) Dilemmas in a general theory of planning. Policy Sciences $4: 155-169$
Roberts N (2000) Wicked problems and network approaches to resolution. International Public Management Review 1(1):119

Santos BS (2010) Para além do pensamento abissal: das linhas globais a uma ecologia de saberes. In: Santos BS, Meneses MP (orgs) Epistemologias do Sul. 2 ed. Almedina/CES, Coimbra, Portugal, pp. 23-71

Santos BS (2020) A Cruel Pedagogia do Vírus. Almedina, Coimbra, Portugal

Santos BS, Meneses MP (orgs) (2010) Epistemologias do Sul. 2 ed. Almedina/CES, Coimbra, Portugal

Saviano M, Barile S, Caputo F, Lettieri M, Zanda $S$ (2019) From rare to neglected diseases: a sustainable and inclusive healthcare perspective for reframing the orphan drugs issue. Sustainability 11(5):1289

Scholz RW, Steiner G (2015) The real type and ideal type of transdisciplinary processes: part I-theoretical foundations. Sustainability Science 10(4):527-544

Shah S (2006) The Body Hunters: Testing New Drugs on the World's Poorest Patients. The New Press, New York, NY, USA

Shrader-Frechette KS, McCoy ED (1993) Method in Ecology: Strategies for Conservation. Cambridge University Press, Cambridge, UK

Smith J (2020) Containing COVID-19 will devastate the economy. Here's the economic case for why it's still our best option (based on the research of M. Eichenbaum, S. Rebelo and M. Trabandt). KellogInsight, 26 March 2020 [https://insight.kellogg.northwestern.edu/article/ economic-cost-coronavirus-recession-coviddeaths] Accessed 10 May 2020

Steffen W, Richardson K, Rockström J, Cornell SE, Fetzer I, Bennett EM, Biggs R, Carpenter SR, de Vries W, de Wit CA, Folke C, Gerten D, Heinke J, Mace GM, Persson LM, Ramanathan V, Reyers B, Sörlin S (2015) Planetary boundaries: guiding human development on a changing planet. Science 347:1259855

Tengö M, Hill R, Malmer P, Raymond CM, Spierenburg M, Danielsen F, Elmqvist T, Folke C (2017) Weaving knowledge systems in IPBES, CBD and beyond - lessons learned for sustainability. Current Opinion in Environmental Sustainability 26-27:17-25 
UNESCO-COMEST (2005) The Precautionary Principle. UNESCO/World Commission on the Ethics of Scientific Knowledge and Technology, Paris, France

USA Today Editorial Board (2020) Coronavirus crisis is a Sputnik opportunity to reverse the anti-science pandemic. USA Today, 13 April 2020 [https://eu.usatoday.com/story/opinion/ todaysdebate/2020/04/13/coronavirus-sputnikopportunity-reverse-anti-science-pandemiceditorials-debates/5103665002/] Accessed 10 May 2020

Van Bavel JJ, Baicker K, Boggio PS, Capraro V, Cichocka A, Cikara M, Crockett MJ, Crum AJ, Douglas KM, Druckman JN, Drury J, Dube O, Ellemers N, Finkel EJ, Fowler JH, Gelfand M, Han S, Haslam SA, Jetten J, Kitayama S, Mobbs D, Napper LE, Packer DJ, Pennycook G, Peters E, Petty RE, Rand DG, Reicher SD, Schnall S, Shariff A, Skitka LJ, Smith SS, Sunstein CR, Tabri N, Tucker JA, van der Linden S, Van Lange PAM, Weeden KA, Wohl MJA, Zaki J, Zion S, Willer R (2020) Using social and behavioural science to support COVID-19 pandemic response. Nature Human Behavior, in press, doi: 10.1038/s41562-020-0884-z Accessed 10 May 2020

Viner RM, Russell SJ, Croker H, Packer J, Ward J, Stansfield C, Mytton O, Bonell C, Booy R
(2020) School closure and management practices during coronavirus outbreaks including COVID-19: a rapid systematic review. Lancet Child \& Adolescent Health 4(5): 397-404

Vogeler I [1981](2019) The land-grant college system. In: The Myth of the Family Farm: Agribusiness Dominance of U.S. Agriculture. Routledge, New York, NY, pp. 195-215

Wang G, Zhang Y, Zhao J, Zhang J, Jiang F (2020) Mitigate the effects of home confinement on children during the COVID-19 outbreak. Lancet 395:945-947

Wilder-Smith A, Freedman DO (2020) Isolation, quarantine, social distancing and community containment: pivotal role for old-style public health measures in the novel coronavirus (2019-nCoV) outbreak. Journal of Travel Medicine 27(2):taaa020

Wu Z, McGoogan JM (2020) Characteristics of and important lessons from the Coronavirus Disease 2019 (COVID-19) outbreak in China: summary of a report of 72314 cases from the Chinese Center for Disease Control and Prevention. JAMA 323(13):1239-1242

Zhang MM, Liu XM, He L (2004) Effect of integrated traditional Chinese and Western medicine on SARS: a review of clinical evidence. World Journal of Gastroenterology 10(23):3500-3505

Received: 14 May 2020

Accepted: 14 May 2020

Published: 18 May 2020 